\title{
Chemical composition and amino acids content of five species of edible Grasshoppers from Mexico
}

\author{
Virginia Melo-Ruiz ${ }^{1 *}$, Horacio Sandoval-Trujillo1, Tomas Quirino-Barreda1', Karina Sánchez-Herrera', \\ Rafael Díaz-García1, Concepción Calvo-Carrillo²
}

${ }^{1}$ UAM-X. Calz. del Hueso 1100. Col. Villa Quietud. Coyoacán, C.P. 04960, México, D. F.; ${ }^{2}$ Instituto Nacional de Ciencias Médicas y Nutrición Salvador Zubirán

\section{A B S TR A C T}

\begin{abstract}
Food security is the main concern of government due to malnutrition worldwide. The aim of this study was to assess macronutrients and amino acids in five species of grasshoppers, consumed in rural and urban communities. Samples were captured in different agro climatic environment conditions, wherever vegetation grows, and the macronutrients were raw, analyzed in dry basis by the AOAC methods and amino acids by cation exchange chromatography. The obtained data showed a high protein content, ranging from $70 \%$ to $75 \%$; lipids $4 \%$ to $6 \%$; minerals $3 \%$ to $5 \%$; fiber $6 \%$ to $8 \%$ and soluble carbohydrates $6 \%$ to $18 \%$, including essential amino acids that play an important role in human metabolism, with tryptophan as limiting factor. The different species of the studied grasshoppers are high in proteins, essential macromolecules for human life that decrease protein-energy malnutrition; the excess of amino acids after releasing the amino group will provide energy, as well as soluble carbohydrates. They also have minerals that are needed to prevent anemia, and fiber, non-digestible carbohydrates essential in a healthy diet. In conclusion, the daily consumption of 5 or 6 grasshoppers is a good source of nutrients that will provide optimal health to population.
\end{abstract}

Keywords: Amino acids; Food; Grasshoppers; Nutrition; Proteins

\section{INTRODUCTION}

Insects have played an important role in the history of human nutrition since prehistoric times, when mammoths that provided a plentiful supply of meat became extinct, and their sources of food and water disappeared due to climatic changes. Wandering groups of people fed themselves with whatever was on hand, such as insects, lizards, snakes, rodents, and anything else remotely edible, and supplement their diets with, seeds, roots, nuts, berries, eggs, and shellfish. The audacious killer of mammoths became hunters of small game and insect collectors (Meyer et al., 2003).

The entomophagy, insect consumption, goes back to the most remote times. Over millennia, people have included in their diet different species of the Orthoptera Order, cooked in various ways, roasted, boiled, smoked, fried, and salted as snack, prepared in stews or as bread in Crimea, Arabia, Persia, Madagascar, Africa, India, Asia, and America (Simmonds, 1859).
In the developed World, insects are viewed as a culinary curiosity and, while it is true, that in some cases in undeveloped or still emerging countries people eat these insects out of necessity, it is the abundance, accessibility, nutritional value, and sensory characteristics that make insects popular as food and a stop to the threat of starvation (Hopkins, 1999).

Grasshoppers are important sources of proteins, formed by complex biomolecules, found in cells, tissues, and other macromolecules involved in nutrition and protein metabolism. Amino acids, the building blocks of proteins with multiple functions and mechanisms of action, also play an important role in human health. They are relevant to dietary intake and requirement considerations (Melo et al., 2011).

The aim of this study was to assess the proteins, amino acids, and other macronutrients in five species of grasshoppers, and to inform people about the importance of their consumption for human health, due to insects' high 
demand in rural communities and urban cities of Mexico, and other countries in the World.

\section{MATERIALS AND METHODS}

\section{Sample collection and preparation}

Convenience sampling of wild insects was performed in several states of Mexico, in different agroclimatic environments, and only one specie was gather in each state, even though there were more than one in the same area (Greenfield and Southgate, 2003). Collection was carried out between 7 and 9 am throughout 2012 . Sphenarium bistrio $S$, adults were manually and net collected in Mexico City, at the Xochimilco demarcation, in a grassy zone in early May. Sphenarium purpurascens $C$ adults were harvested late June in Oaxaca, at grassland. Melanoplus femurrubrum $D$ adults were obtained nearby an alfalfa field early August, at Huejotzingo Puebla. Taeniopoda equse $B$ adults were gathered nearby a corn field, in early October, in Atlixco, Puebla. Schistocerca spp insects were obtained in a xerophyte thicket, late June at Actopan, Hidalgo. Insects were washed under running tap water and rinsed with distilled water and sun dried to be transported in glass containers to the University for Taxonomic Identification (Cibrián et al., 1995; Anaya Rosales et al., 2000; Morón and Terrón, 2011). Legs and wings were removed; individuals were homogenized by weight each one to $0.5 \mathrm{~g}$ for all samples and $0.7 \mathrm{~g}$ for Schistocerca spp which adult stage is much bigger, and further proceed with chemical analysis.

\section{Determination of moisture content}

Moisture content of samples was determined using the direct drying method. Homogenized sample by weight of each organism, $(10 \mathrm{~g})$ was dried in an oven at $60^{\circ} \mathrm{C}$ for $24 \mathrm{hrs}$. The samples were powdered in a mortar then passed through a 60 mesh size. The obtained fine powder was used for further analysis.

\section{Determination of ash}

Ash was obtained by incinerating at $650^{\circ} \mathrm{C}$ in a muffle furnace for $6 \mathrm{~h}$ to a constant weight, to eliminate organic matter.

\section{Determination of lipid content}

Lipid content determination was performed by the semi continuous solvent extraction method (AOAC Method 934.01) as follows: ten grams of the sample were extracted with $180 \mathrm{ml}$ petroleum ether on a Soxhlet apparatus for $10 \mathrm{~h}$. Petroleum ether was removed by evaporation and the lipid residue was weighed. All samples were analyzed by triplicate and the results are expressed as $\mathrm{g} / 100 \mathrm{~g}$ dry basis of sample.

\section{Determination of protein content}

Protein content of sample was determined according to the principle of the Kjeldahl method (AOAC Method 945.01). Sample (1 g) was digested with $15 \mathrm{ml}$ concentrated sulphuric acid, using an electrically heated aluminum block digester. The resulting digest was diluted and then made

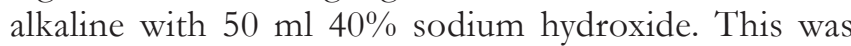
followed by rapid steam distillation of ammonia from the diluted digest into $25 \mathrm{ml} \mathrm{4 \%}$ boric acid for manual titration with $0.2 \mathrm{~N}$ hydrochloric acid. A conversion factor of 6.25 was used to convert the measured nitrogen content to protein content. All samples were analyzed in triplicate and the results are expressed as $\mathrm{g} / 100 \mathrm{~g}$ dry basis of sample (Osborne, 1985; Pearson, 1989).

\section{Determination of total available carbohydrate content}

The total available carbohydrate content of sample was determined by the Clegg-anthrone method (Peris-Torjada, 2004). Sample (1 g) was digested with $13 \mathrm{ml} \mathrm{52 \%} \mathrm{perchloric}$ acid to hydrolyze disaccharides, trisaccharides and higher oligomers to their component reducing sugars and reacted with anthrone reagent under acid condition to produce a blue/green color. Anthrone reagent was prepared by dissolving $0.1 \%(\mathrm{w} / \mathrm{v})$ anthrone in diluted sulphuric acid (sulphuric acid: water in ratio of 2.3:1.0, v/v). An aliquot $(1 \mathrm{ml})$ of diluted hydrolysate was mixed with $5 \mathrm{ml}$ anthrone reagent. Absorbance of the reaction mixture was measured at $630 \mathrm{~nm}$ against a blank after incubated in boiling water for $12 \mathrm{~min}$ and cooled. All samples were analyzed in triplicate. Glucose (0-100 mg/L) was used to construct a standard curve for quantification and the results are expressed as $\mathrm{g} / 100 \mathrm{~g}$ dry basis of sample.

\section{Determination of amino acids}

The Grasshoppers samples were dried and grind to powder, in an oven and degreased with petroleum ether. The samples for amino acid analyses were hydrolyzed in constant with $6 \mathrm{~N} \mathrm{HCl}$ for $24 \mathrm{hr}$. at $110^{\circ} \mathrm{C}$ (Gehrke et al., 1987), evaporated under vacuum stream, the sample is then resuspended in the NA-S buffer and injected to the system. For the analysis of methionine and cysteine samples were oxidized by performic acid before hydrolysis (Moore, 1963). Amino acids were determined by HPLC technique, using an automatic auto analyzer Beckman System Gold model 6300 that includes a solvent module 126AA, post column reactor 232, detector 166 , autosampler 507, a column of cation exchange resin (3x250 mm spherogel AA lithium column (sulfonated polystyrene-divinylbenzene copolymers)), and a computer work station, diluted with a gradient of buffers with a concentration of $0.2 \mathrm{M}$ to $2 \mathrm{M}$ of citrate and $\mathrm{pH} 3.1$ to 5.6 (Beckman, 1985). Tryptophan was measured according to a colorimetric method after enzymatic hydrolysis by Pronase (Spies and Chambers, 1949; Holz, 1972). Duplicated analyses were carried out for each sample. 


\section{Statistical analysis}

Three independent analyses were done for each determination and each grasshopper, only in the determination of amino acids the analyses were done in two samples. The results are expressed as the average.

\section{RESULTS AND DISCUSSION}

Season for insect availability is shown in Table 1. Nomenclature and name of insects studied Table 2.

\section{Moisture and macronutrients composition}

Convenience manual sampling was performed in some Mexican states with different agro climatic conditions: in Xochimilco, in grassy land, in spring, with seldom rains; in Oaxaca, in grassland, during early summer, with regular heavy rains; in Puebla, some were harvested in alfalfa fields during summer with heavy rain and other species in a corn field, early autumn without rains; in Hidalgo, in an arid zone with xerophyte thicket, early summer but with exceptional heavy rain. Insects get water and food from surrounding environments, therefore characteristics of the environment might slightly change their water and macronutrient content. Almost one third part of the insect is water (Table 3).

Moisture in grasshoppers ranks from $35.29 \%$ to $43.19 \%$ and dry samples from $56.81 \%$ to $64.71 \%$. Data correspond to: Sphenarium histrio S: $37.02 \%$ and $62.96 \%$; Sphenarium purpurascens Ch: $41.44 \%$ and 58.56\%; Taeniopoda eques B: $35.29 \%$ and 64.71\%; Melanoplus femurrubrum D: 39.82\%

Table 1: Grasshopper's availability through the year

\begin{tabular}{|c|c|c|c|c|c|c|c|c|c|c|c|c|}
\hline Species/month & $\mathrm{J}$ & $F$ & M & A & M & $\mathrm{J}$ & $\mathrm{J}$ & A & $\mathrm{s}$ & 0 & & D \\
\hline Sphenarium histrio S & $x$ & $x$ & $x$ & $\mathrm{x}$ & $x$ & $\mathrm{x}$ & $x$ & $\mathrm{x}$ & $x$ & $x$ & & $x$ \\
\hline Sphenarium purpurascens Ch & & & & & $x$ & $x$ & $x$ & $x$ & $x$ & $x$ & $\mathrm{x}$ & $x$ \\
\hline Taeniopoda eques B & & & & & & $x$ & $x$ & $x$ & $x$ & $x$ & $x$ & \\
\hline Melanoplus femurrubrum D & & & & & $x$ & $x$ & $x$ & $X$ & $x$ & $X$ & $x$ & \\
\hline Schistocerca spp. & & & & & & $x$ & $x$ & $x$ & $x$ & $x$ & $x$ & $\mathrm{X}$ \\
\hline
\end{tabular}

Table 2: Nomenclature of sample species (Morón and Terrón, 2011)

\begin{tabular}{llllll}
\hline Order & Orthoptera & Orthoptera & Orthoptera & Orthoptera & Orthoptera \\
\hline Family & Acrididae & Acrididae & Acrididae & Acrididae & Acrididae \\
Genus & Sphenarium & Sphenarium & Taeniopoda & Melanoplus & Schistocerca \\
Specie & histrio S & purpurascens Ch & eques B & femurrubrum D & spp \\
Common name & Grasshopper & Grasshopper & Grasshopper & Grasshopper & Grasshopper \\
\hline
\end{tabular}

Table 3: Moisture determination of 5 Grasshopper species (\%)

\begin{tabular}{lccccc}
\hline Species & $\begin{array}{c}\text { Sphenarium } \\
\text { histrio S }\end{array}$ & $\begin{array}{c}\text { Sphenarium } \\
\text { Purpurascens } \text { Ch }\end{array}$ & $\begin{array}{c}\text { Taeniopoda } \\
\text { Eques B }\end{array}$ & $\begin{array}{c}\text { Melanoplus } \\
\text { femurrubrum D }\end{array}$ & $\begin{array}{c}\text { Schistocerca } \\
\text { spp }\end{array}$ \\
\hline Moisture & 37.04 & 41.44 & 35.29 & 39.82 & 43.19 \\
Dry sample & 62.96 & 58.56 & 64.71 & 60.18 & 56.81 \\
\hline
\end{tabular}

and $60.18 \%$; Schistocerca spp: $43.19 \%$ and $56.81 \%$ of water and dry matter respectively. Sphenarium purpurascens $\mathrm{Ch}$, Melanoplus femurrubrum D and Schistocerca spp present the higher content of water because they were collected in rainy season and Sphenarium histrio S and Taeniopoda eques B were the lower in water because capture were on dry season and insects get water from environment.

Proteins are one of the five classes of biomolecules found in cells and tissues; the others are polysaccharides, lipids, and some minerals (Brosnan and Young 2003). Macronutrient data for each species raw analyzed on dry basis was: proteins from $62.5 \%$ to $77.25 \%$ of the total weight. The determined protein content of grasshoppers was very high, from $62.5 \%$ to $77.25 \%$, however the excess is not toxic for once the metabolism obtains the required proteins, the amino group of the amino acids is removed, the remaining part can provide energy; total lipids in dry samples were low in four species from $4.71 \%$ to $6.2 \%$, except Shistocerca spp that content $16.0 \%$; minerals ranked from $2.05 \%$ to $4.5 \%$ (minerals were not analyze individually); crude fiber 7.08\% to $11.15 \%$; and soluble carbohydrates (source of energy) were low but excess of proteins would bring energy to complement requirements $6.66 \%$ to $9.59 \%$. Crude Fiber, carbohydrate polymers not hydrolysed by endogenous enzymes, were $4.84 \%$ to $9.59 \%$ (Table 4 ).

Energetic value was calculated multiplying soluble carbohydrates and proteins by 4 and lipids by 9 , to obtain the Kcal amount.

There are 20 amino acids that are the basic components of proteins, and which play an important role in human metabolism. From these, 8 are essential for adults and 10 for children; their study is focused in them providing nitrogen to the organism, for proteins are the only source of this energetic income (Duffy et al., 1981).

In addition to their role as substrates for the polypeptide chain formation, amino acids serve multiple and diverse 
functions in human health, such as: leucine, regulator of protein turnover, transporter of nitrogen in the brain, and translation regulator; arginine, regulator of enzyme activity and precursor of signal transducer; glutamine, substrate of protein synthesis, for hepatic and renal gluconeogenesis, control for acid-base balance; phenylalanine, regulator for enzyme activity; tryptophan, neurotransmitter; alanine, nitrogen transporter (Duffy et al., 1981; Pencharz, 2012). These are only some of them. In pleasurable taste sensation "umami taste", glutamine is responsible for enhance the sensory qualities of various foods (Table 5).

The amino acids content calculated as $16 \mathrm{~g} \mathrm{~N}$ reflected that regarding essential amino acids, tryptophan is the limiting one, compared with the standard (FAO/WHO/ UNU 2007) in all species of grasshoppers, sulphur amino acids was also lower in Sphenarium purpurascens $C h$ and Schistocerca spp and lysine in Melanoplus femrrubrum D, in nonessential amino acids glutamic acid with an important role in nutrition is high in all species but Shpenarium histrio $S$. (Table 5).

\section{CONCLUSIONS}

Protein is the fundamental component for cellular and organ functions, thus its deficiency has adverse effects on human health. By incorporating grasshoppers and other insects to daily diets, most people would contain not only enough protein and amino acids, but also sufficient nonprotein energy to permit the optimal use of dietary protein. Chemical composition could slightly change, according location, environment conditions and time after insect hatch. Grasshoppers found worldwide, wherever any vegetation grows, range in size, from one to five inches in length, are the most popular edible insect, dating back at least to Old Testament times, since then grasshoppers, raw or in different preparations, as snacks or as a culinary staple are intake, they are affordable to all social groups, therefore, insects may represent a good option to improve food security worldwide.

\section{Author contributions}

V. M. R. was involved in overall planning and supervision. H. S. T. made major contributions to the review paper.

Table 4. Macronutrients of 5 Grasshoppers species (g/100g dry basis)

\begin{tabular}{|c|c|c|c|c|c|}
\hline Species & $\begin{array}{l}\text { Sphenarium } \\
\text { histrio S }\end{array}$ & $\begin{array}{c}\text { Sphenarium } \\
\text { purpurascens Ch }\end{array}$ & Taeniopodaeques B & $\begin{array}{c}\text { Melanoplus } \\
\text { femurrubrum D }\end{array}$ & $\begin{array}{c}\text { Schistocerca } \\
\text { spp }\end{array}$ \\
\hline Proteins & $77.25 \pm 0.7$ & $75.87 \pm 0.6$ & $71.05 \pm 0.7$ & $74.7 \pm 0.7$ & $62.5 \pm 0.6$ \\
\hline Lipids & $4.71 \pm 0.9$ & $6.02 \pm 1.1$ & $5.85 \pm 1.3$ & $5.23 \pm 1.1$ & $16.0 \pm 1.8$ \\
\hline Minerals & $2.05 \pm 0.2$ & $2.52 \pm 0.2$ & $2.95 \pm 0.2$ & $3.4 \pm 0.3$ & $4.5 \pm 0.3$ \\
\hline Crude fiber & $11.15 \pm 0.7$ & $7.08 \pm 0.9$ & $10.56 \pm 1.1$ & $10.01 \pm 0.9$ & $10.05 \pm 0.8$ \\
\hline Soluble carbohydrates & $4.84 \pm 0.1$ & $8.51 \pm 0.2$ & $9.59 \pm 0.2$ & $6.66 \pm 0.2$ & $6.95 \pm 0.3$ \\
\hline Energetic value (Kcal/100g) & 370.75 & 391.7 & 375.21 & 372.51 & 421.8 \\
\hline
\end{tabular}

All values are mean of triplicate determination. Proteins: Kjeldahl N x 6.25

Table 5. Amino acid composition ( $\mathrm{g} / 16 \mathrm{~g}$ Nitrogen) of the $5 \mathrm{grasshopper} \mathrm{species}$

\begin{tabular}{|c|c|c|c|c|c|c|}
\hline \multicolumn{6}{|c|}{ Essential amino acids } & \multirow{2}{*}{$\begin{array}{c}\text { FAO } \\
\text { Pattern } \\
1973\end{array}$} \\
\hline Species/amino acids & $\begin{array}{l}\text { Sphenarium } \\
\text { histrio S }\end{array}$ & $\begin{array}{c}\text { Sphenarium } \\
\text { purpurascens Ch }\end{array}$ & $\begin{array}{c}\text { Taeniopoda } \\
\text { eques B }\end{array}$ & $\begin{array}{c}\text { Melanoplus } \\
\text { femurrubrum D }\end{array}$ & $\begin{array}{c}\text { Schistocerca } \\
\text { spp }\end{array}$ & \\
\hline Isoleucine & $5.6 \pm 0.2$ & $4.5 \pm 0.2$ & $4.1 \pm 0.3$ & $4.7 \pm 0.1$ & $5.3 \pm 0.2$ & 4.00 \\
\hline Leucine & $8.5 \pm 0.3$ & $8.7 \pm 0.2$ & $7.2 \pm 0.2$ & $8.8 \pm 0.2$ & $7.9 \pm 0.2$ & 7.00 \\
\hline Lysine & $5.2 \pm 0.1$ & $5.7 \pm 0.1$ & $3.1 \pm 0.2$ & $2.7 \pm 0.2$ & $5.1 \pm 0.2$ & 5.5 \\
\hline Methionine+Cysteine & $3.1 \pm 0.2$ & $2.9 \pm 0.2$ & $6.8 \pm 0.3$ & $6.9 \pm 0.4$ & $2.8 \pm 0.2$ & 3.5 \\
\hline Phenylalanine+Tyrosine & $6.1 \pm 0.2$ & $6.3 \pm 0.3$ & $4.3 \pm 0.2$ & $5.2 \pm 0.3$ & $6.3 \pm 0.2$ & 6.0 \\
\hline Threonine & $4.3 \pm 0.1$ & $3.9 \pm 0.2$ & $4.5 \pm 0.1$ & $4.1 \pm 0.2$ & $4.1 \pm 0.2$ & 4.0 \\
\hline Tryptophan & $0.5 \pm 0.1$ & $0.6 \pm 0.2$ & $0.6 \pm 0.2$ & $0.5 \pm 0.1$ & $0.4 \pm 0.2$ & 1.0 \\
\hline Valine & $5.4 \pm 0.2$ & $5.7 \pm 0.1$ & $5.4 \pm 0.1$ & $5.2 \pm 0.3$ & $5.1 \pm 0.2$ & 5.1 \\
\hline \multicolumn{7}{|c|}{ No essential amino acids } \\
\hline Histidine & $1.3 \pm 0.1$ & $2.7 \pm 0.2$ & $2.4 \pm 0.1$ & $1.8 \pm 0.2$ & $1.9 \pm 0.2$ & \\
\hline Aspartic acid & $9.5 \pm 0.4$ & $9.8 \pm 0.3$ & $9.8 \pm 0.2$ & $10.1 \pm 0.3$ & $10.7 \pm 0.4$ & \\
\hline Glutamic acid & $4.5 \pm 0.2$ & $10.80 \pm 0.4$ & $8.4 \pm 0.2$ & $15.2 \pm 0.5$ & $11.8 \pm 0.3$ & \\
\hline Serine & $4.9 \pm 0.2$ & $4.5 \pm 0.2$ & $4.9 \pm 0.2$ & $4.7 \pm 0.2$ & $5.1 \pm 0.1$ & \\
\hline Proline & $6.9 \pm 0.3$ & $6.5 \pm 0.3$ & $6.7 \pm 0.3$ & $6.1 \pm 0.2$ & $6.3 \pm 0.2$ & \\
\hline Glycine & $5.4 \pm 0.2$ & $5.2 \pm 0.2$ & $4.7 \pm 0.2$ & $5.5 \pm 0.2$ & $5.2 \pm 0.2$ & \\
\hline Alanine & $7.5 \pm 0.3$ & $7.1 \pm 0.2$ & $9.8 \pm 0.3$ & $10.4 \pm 0.4$ & $6.9 \pm 0.2$ & \\
\hline Arginine & $6.4 \pm 0.1$ & $6.5 \pm 0.2$ & $6.8 \pm 0.2$ & $6.9 \pm 0.2$ & $7.1 \pm 0.2$ & \\
\hline
\end{tabular}

Asparagine and glutamine can be synthesized from aspartic acid and glutamic acid. Samples were analyzed in duplicate 
T. Q. B. was involved in overall laboratory work. K. S. H. was involved in overall laboratory work and review paper. R. D. G. was involved in overall laboratory work and review paper. C. C. C. was involved in overall planning, supervision and review paper.

\section{REFERENCES}

Anaya, R. S., N. J. Romero and M. V. López. 2000. El manual de diagnóstico para las especies de Chapulín (Orhoptera: Acridoidea) del Estado de Tlaxcala y Estados adyacentes, Colegio de Postgraduados. Texcoco, Estado de México, México.

AOAC. 1995. Official methods of analysis. $15^{\text {th }}$ ed. Association of Official Analytical Chemists, Washington, DC.

Beckman. 1985. The System 6300 series high performance amino acids analyzer. Instruction manual. Spinco Division of Beckman, Division Instruments. Palo Alto, California, p218.

Brosnan, J. T. and V. R. Young. 2003. Integration of metabolism 2: Protein and amino acids. J. M. Gibney, I. A. Macdonald and M. H. Roche, editors, Nutrition \& Metabolism. Blackwell Publishing, USA.

Duffy, B., T. Gunn and J. Collinge. 1981. The effect of varying protein quality and energy intake on the nitrogen metabolism of parentally fed very low birth weight infants. Pediatr. Res. 15: 1040-1044.

Cibrián, T. D., M. J. T. Méndez, B. R. Campos, H. O. Yates III and L. J. Flores. 1995. Insectos forestales de México/ Forest Insects of Mexico. Universidad Autónoma de Chapingo, Chapingo, México.

FAO/WHO/UNU. 2007. Protein and amino acids requirements in human nutrition: Report of a Joint FAO/WHO/UNU Expert Consultation. WHO Technical Series, 935. Available from: http:// www.whqlib-doc.who.int/trs/WHO_TRS_935_eng.pdf. [Last accessed on 2009 Aug 17].

Gehrke, C. W., P. R. Rexroad, R. M. Schisla, J. S. Absheer and R. W. Zumwalt. 1987. Quantitative analysis of cysteine, methionine, lysine and nine other amino acids by a single oxidation-4 hours hydrolysis method. J. Assoc. Off. Anal. Chem. 70: $171-174$.

Greenfield, H. and D. A. T. Southgate. 2003. Food Composition Data. Production Management and Use. $2^{\text {nd }}$ ed. Publisher FAO, Rome. p63-82.

Holz, F. 1972. Automatic determination of tryptophan in proteins and protein-containing plant products with dimethylamino cinnamaldehyde, Landwirsh Forsh Sonderh. 27: 96-109.

Hopkins, J. 2004. Extreme Cuisine. Periplus Editions (HK) Ltd., Singapore, p190-193.

Melo, V., M. García, H. Sandoval, H. D. Jiménez and C. Clvo. 2011. Quality proteins from edible indigenous insect food of Latin America and Asia. Emir. J. Food Agric. 23: 283-289.

Meyer, M. C., W. L. Sherman and S. M. Deeds. 2003. The Course of Mexican History. Oxford University Press, New York.

Moore, S. 1963. On the determination of cysteine as cystine acid. J. Biol. Chem. 238: 235-237.

Morón, M. A. and Terrón, R. A. 2011. Entomología Práctica. Instituto de Ecología, México, D.F.

Osborne, D. R. 1985. Análisis de Nutrientes de Los Alimentos. Acribia, España.

Pearson, D. 1989. Técnicas de Laboratorio Para el Análisis de Alimentos. Acribia, España.

Pencharz, P. B. 2012. Proteins and amino acids. In: Erdman, J. W. Jr., Macdonald, I. A., Zeisel, S. H. editors. Present Knowledge in Nutrition. $10^{\text {th }}$ ed. ILSI, International Life Sciences Institute. Wiley-Blackwell, John Wiley \& Sons, Ltd., Singapore.

Peris-Torjada. 2004. Carbohydrates and starch. Leo, M. L. N. editors. Handbook of Food Analysis: Physical Characterization and Nutrient Analysis. Marcel-Dekker, Inc., USA.

Simmonds, P. L. 1859. Dainties and delicacies of different nations obtained from the animal kingdom. Richard Bentley, London.

Simmonds, P. L. 2001. The Curiosities of Food. Facsimile Edition. Ten Speed Press, Berkeley, California, p296-304.

Spies, J. R. and D. C. Chambers. 1949. Chemical determination of tryptophan in proteins. Anal. Chem. 21: 1249-1266. 